\title{
ANALISIS BIAYA PENGENDALIAN GULMA MANUAL PADA TANAMAN BELUM MENGHASILKAN (TBM) DI PT. SENTOSA KALIMANTAN JAYA
}

\section{ANAL YSIS OF MANUAL SUGAR CONTROL COSTS IN PLANTS NOT YET PRODUCED (TBM) IN PT. SENTOSA KALIMANTAN JAYA}

\author{
Setia Budi*1, Rusli Anwar ${ }^{1}$, Rusmini ${ }^{1}$ \\ ${ }^{1}$ Politeknik Pertanian Negeri Samarinda, Kampus Gunung Panjang, Jl. Samratulangi, \\ Samarinda, Indonesia \\ setibudi7@gmail.com
}

\begin{abstract}
This research is based on the background that weeds in oil palm plantations must be controlled so that economically it does not affect production. The implementation of manual weed control on immature plants (TBM) must have used costs that must be incurred by the company. This study aims to analyze the cost of controlling weeds manually and to identify the factors that affect the cost of controlling weeds in immature plants (TBM).

The implementation of this research uses quantitative methods in analyzing costs at 2 work units (Afdeling) by using data on the implementation / realization of work for February-April 2019 and descriptive methods in identifying factors that affect costs by conducting field analysis. The results of the cost analysis in 2 afdeling get results in the form of the average Afdeling cost, namely: The cost of manually controlling weeds in the gawangan at Afdeling 1 is Rp. 254,756 / ha and the gawangan at Afdeling 2 is Rp. 261,242 / ha. Meanwhile, the cost of controlling weeds manually on the plate at Afdeling 1 is Rp. 254,483 / ha and the plate at Afdeling 2 Rp. 238,787 / ha. Factors that influence the cost of controlling weeds manually in immature plants (TBM), especially in the dish and in the fields are more due to factors of land topography, weed density, and the types of weeds that are controlled.
\end{abstract}

Keywords: Cost, Manual Weed Control, Gawangan and Disc.

\section{PENDAHULUAN}

Kelapa sawit (Elaeis guineensis Jacq) merupakan salah satu tanaman perkebunan di Indonesia yang memiliki masa depan cukup cerah. Perkebunan kelapa sawit semula berkembang di daerah Sumatera Utara dan Nanggroe Aceh Darussalam. Namun sekarang telah berkembang ke berbagai daerah seperti, Riau, Jambi, Sumatera Barat, Sumatera Selatan, Bengkulu, Lampung, Sulawesi, Maluku, Papua, Jawa Barat, Kalimantan Barat, Kalimantan Tengah dan Kalimantan Timur (Sunarko, 2007).

Menurut Purwanto (2016) tanaman kelapa sawit adalah tanaman penghasil minyak nabati yang dapat menjadi andalan dimasa depan karena berbagai kegunaannya bagi kebutuhan manusia. Kelapa sawit memiliki arti penting bagi pembangunan nasional Indonesia. Selain menciptakan kesempatan kerja yang mengarah pada kesejahteraan masyarakat, juga sebagai sumber devisa negara (Purwanto, 2016).

Gulma di perkebunan kelapa sawit harus dikendalikan supaya secara ekonomi tidak berpengaruh secara nyata terhadap hasil produksi. Adanya gulma di perkebunan kelapa sawit akan merugikan. Alasannya, gulma akan menghambat jalan para pekerja (terutama gulma-gulma yang berduri), gulma menjadi pesaing tanaman kelapa sawit dalam menyerap unsur hara dan air, serta kemungkinan gulma menjadi tanaman inang bagi hama atau penyakit yang menyerang tanaman kelapa sawit (Sastrosayono, 2003).

Pada dasarnya perusahaan menerapkan dua cara dalam pengendalian gulma pada perkebunan kelapa sawit, yaitu secara manual dan secara kimia. Pengendalian gulma secara manual adalah menggunakan alat dan tenaga secara langsung. Pelaksanaan kegiatan pengendalian 
gulma secara manual pada tanaman belum menghasikan (TBM) pasti ada penggunaan biaya yang harus dikeluarkan oleh perusahaan.

Penelitian yang dilakukan ini terbatas hanya pada suatu lingkup Afdeling yang memiliki luasan berkisar antara 500 ha sampai dengan 700 ha. Objek dalam penelitian ini adalah kegiatan pengendalian gulma secara manual yang diterapkan oleh perusahaan, terfokus pada kajian perhitungan biaya pengendalian gulma pada tanaman belum menghasilkan (TBM) yang mencangkup komponen perhitungan biaya tenaga kerja dan alat Penelitian ini bertujuan untuk menganalisis biaya pengendalian gulma secara manual serta mengidentifikasi faktor yang mempengaruhi biaya pengendalian gulma pada tanaman belum menghasilkan (TBM). Hasil penelitian ini diharapkan dapat memberikan gambaran tentang biaya persatuan hektar serta biaya perkomponen kegiatan tersebut. Pada penelitian ini juga diketahui faktor-faktor yang mempengaruhi besar kecilnya biaya antar Afdeling yang satu dengan Afdeling yang lain.

\section{METODOLOGI}

\section{Data Primer}

\section{a. Pengamatan Lapangan}

Pengamatan lapangan dilakukan secara langsung di lapangan dengan cara melakukan pengambilan data melalui kegiatan di lapangan berupa kondisi lapangan, proses kegiatan kerja dan hasil kegiatan.

b. Dokumentasi

Pengambilan gambar mengenai pelaksanaan kegiatan pengendalian gulma yang dilakukan di lapangan guna menunjang dalam penelitian.

\section{Data Sekunder}

a. Laporan Hasil Kegiatan Pengendalian Gulma dari Perusahaan

Mengumpulkan dan menganalisis data hasil kegiatan pengendalian gulma secara manual dari perusahaan yang berhubungan dengan biaya pengendalian gulma secara manual dan data lain untuk mendukung penelitian yang terdapat pada perusahaan khususnya pada Afdeling tempat penelitian.

b. Studi Pustaka

Mengumpulkan informasi yang bersumber dari buku, internet serta dokumen lain yang dapat dipertanggung jawabkan sebagai informasi pendukung penelitian di lapangan.

\section{HASIL DAN PEMBAHASAN}

\section{Hasil}

\section{Biaya Pengendalian Gulma Manual}

Dalam pelaksanaan kegiatan pengendalian gulma secara manual di lokasi penelitian dapat diidentifikasi penggunaan biaya yang meliputi biaya tenaga kerja dan biaya alat dari hasil pengolahan data penggunaan biaya pengendalian gulma pada Afdeling 1 dan 2 di PT. SKJ, sebagaimana disajikan dalam analisis biaya sebagai berikut:

a. Biaya Afdeling 1

Hasil analisis biaya pada Afdeling 1 untuk pelaksanaan kegiatan pengendalian gulma secara manual pada gawangan bulan Februari hingga April 2019 (Lampiran 2). Secara rinci kebutuhan biaya pengendalian gulma manual pada gawangan dapat dilihat pada Tabel 1.

Berdasarkan data yang disajikan pada Tabel 1 dapat dijelaskan bahwa dalam kegiatan pengendalian gulma manual pada gawangan, Afdeling 1 pada bulan Februari hingga April 2019 tenaga kerja membutuhkan 94.3 Hari Kerja (HK) dengan biaya sebesar Rp 11.772.412, dimana setiap HK membutuhkan biaya sebesar Rp. 124.840 untuk masa kerja selama 7 jam dalam satu hari.

Penggunaan alat parang sebanyak 3,75 unit dan membutuhkan biaya sebesar Rp.184.800, sedangkan batu asah sebanyak 3,75 unit dan membutuhkan biaya Rp. 36.728 . Penggunaan alat berupa parang dan batu asah memiliki waktu ekonomis selama 1 tahun, Pada periode 2019 Afdeling 1 melakukan permintaan masing- masing sebanyak 15 unit di 
porposikan menjadi 3,75 unit dengan biaya parang $R p$ 49.280/unit, biaya batu asah Rp. 9.794 /unit untuk waktu penggunaan 3,75 unit parang dan batu asah selama 3 bulan membutuhkan biaya masing-masing sebesar parang Rp 184.800, batu asah Rp. 36.728. Analisis biaya pengendalian gulma di Afdeling 1 juga dilakukan terhadap kegiatan pengendalian gulma di piringan manual (Lampiran 3). Dari hasil analisis yang dilaksanakan pada kegiatan pengendalian gulma secara manual pada piringan untuk bulan Februari hingga April 2019 secara rinci dapat dilihat pada Tabel 2

Tabel 1. Biaya pengendalian gulma secara manual pada gawangan Afdeling 1 bulan Februari hingga April 2019

\begin{tabular}{|c|c|c|c|c|c|}
\hline No & $\begin{array}{l}\text { Komponen } \\
\text { Biaya }\end{array}$ & Satuan & $\begin{array}{c}\text { Jumla } \\
\mathrm{h}\end{array}$ & $\begin{array}{c}\text { Jumlah/satuan } \\
\text { (RP) }\end{array}$ & Jumlah biaya (RP) \\
\hline 1 & $\begin{array}{l}\text { Tenaga kerja } \\
1.1 \text { Upah }\end{array}$ & HK & 94.3 & Rp. 124.840 & Rp. 11.772 .412 \\
\hline \multicolumn{2}{|c|}{ Sub total } & & & & Rp. 11.772.412 \\
\hline \multirow[t]{3}{*}{2} & Alat & & & & \\
\hline & 2.1 Parang & Unit & 3,75 & Rp. 49.280 & 184.800 \\
\hline & 2.2 Batu Asah & Unit & 3,75 & 9.794 & 36.728 \\
\hline \multicolumn{2}{|c|}{ Sub Total } & & & & Rp. $\quad 221.528$ \\
\hline \multicolumn{2}{|c|}{ Jumlah } & & & & Rp. 11.993.940 \\
\hline
\end{tabular}

Tabel 2. Biaya pengendalian gulma secara manual pada piringan Afdeling 1 bulan Februari hingga April 2019

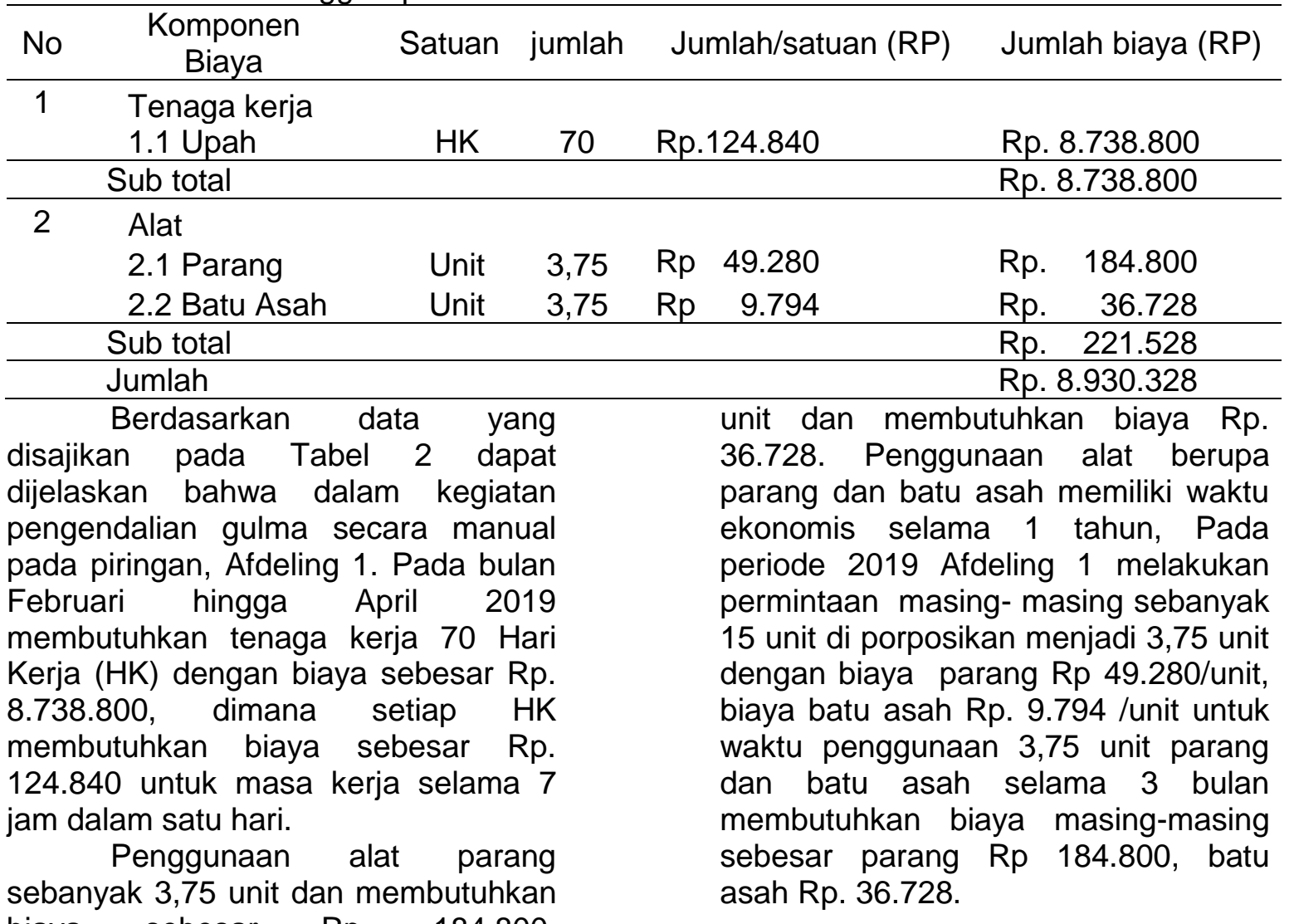

biaya sebesar Rp. 184.800, sedangkan batu asah sebanyak 3,75 
b. Biaya Afdeling 2

Hasil analisis biaya pada Afdeling 2 untuk pelaksanaan kegiatan pengendalian gulma secara manual pada gawangan bulan Februari hingga April 2019. Secara rinci dapat dilihat pada Tabel 3.

Tabel 3. Biaya pengendalian gulma secara manual pada gawangan Afdeling 2 bulan Februari hingga April 2019

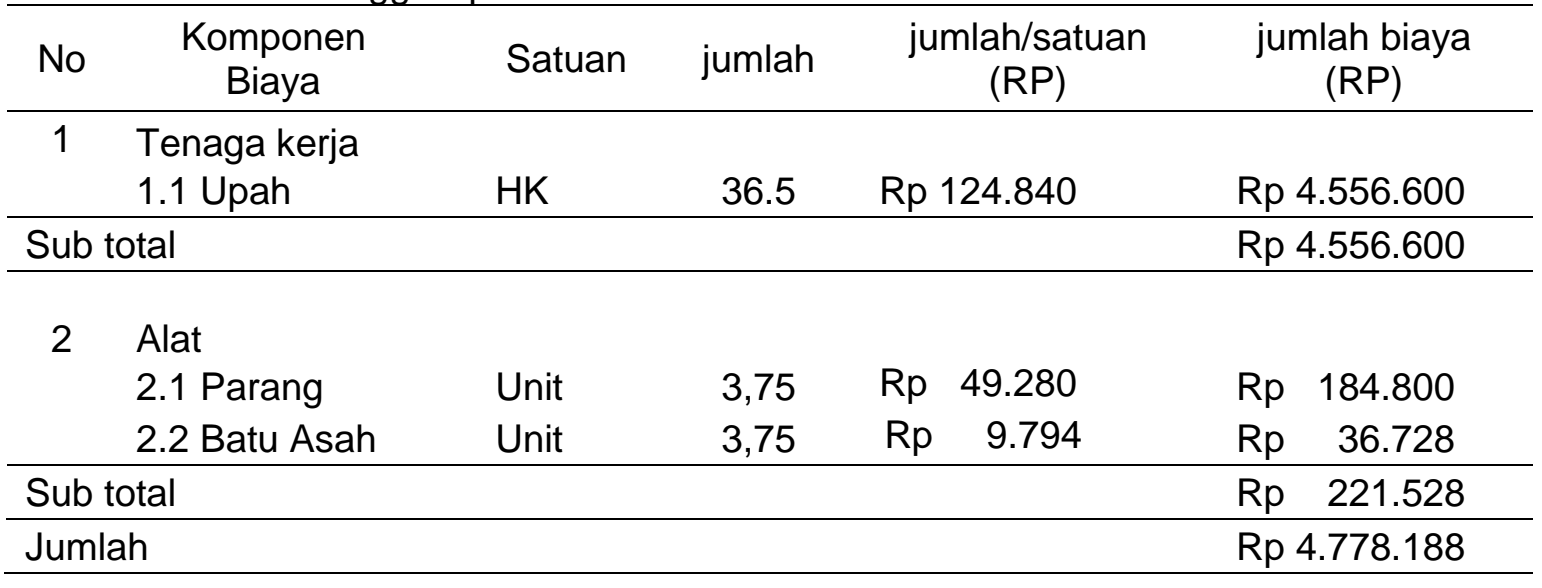

Tabel 4. Biaya pengendalian gulma secara manual pada piringan Afdeling 2 bulan Febuari hingga April 2019

No Komponen Biaya Satuan Jumlah Jumlah/satuan (Rp) $\begin{gathered}\text { Jumlah biaya } \\ (\mathrm{Rp})\end{gathered}$

\begin{tabular}{|c|c|c|c|c|c|c|}
\hline 1 & $\begin{array}{l}\text { Tenaga kerja } \\
1.1 \text { Upah }\end{array}$ & $\mathrm{HK}$ & 34.3 & \multicolumn{2}{|c|}{ Rp. 124.840} & Rp. 4.282.012 \\
\hline \multicolumn{2}{|c|}{ Sub total } & & & & & Rp. 4.282.012 \\
\hline \multirow[t]{3}{*}{2} & Alat & & & & & \\
\hline & 2.1 Parang & Unit & 3,75 & $\mathrm{Rp}$ & 49.280 & Rp. 184.800 \\
\hline & 2.2 Batu Asah & Unit & 3,75 & $\mathrm{Rp}$ & 9.794 & Rp. $\quad 36.728$ \\
\hline \multicolumn{2}{|c|}{ Sub total } & & & & & $\begin{array}{ll}\text { Rp. } & 221.528 \\
\end{array}$ \\
\hline \multicolumn{2}{|c|}{ Jumlah } & & & & & Rp. 4.503.540 \\
\hline
\end{tabular}

Berdasarkan data yang disajikan pada Tabel 3 dapat dijelaskan bahwa dalam kegiatan pengendalian gulma manual pada gawangan, Afdeling 2 pada bulan Februari hingga April 2019 membutuhkan tenaga kerja 36.5 Hari Kerja (HK) dengan biaya sebesar Rp. 4.556.600, dimana setiap HK membutuhkan biaya sebesar Rp. 124.840 untuk masa kerja selama 7 jam dalam satu hari.

Penggunaan alat parang sebanyak 3,75 unit dan membutuhkan biaya sebesar Rp. 184.800, sedangkan batu asah sebanyak 3,75 unit dan membutuhkan biaya Rp. 36.728. Penggunaan alat berupa parang dan batu asah memiliki waktu ekonomis selama 1 tahun, Pada periode 2019 Afdeling 1 melakukan permintaan masing- masing sebanyak 15 unit di porposikan menjadi 3,75 unit dengan biaya parang Rp 49.280/unit, biaya batu asah Rp. 9.794 /unit untuk waktu penggunaan 3,75 unit parang dan batu asah selama 3 bulan membutuhkan biaya masing-masing sebesar parang Rp 184.800, batu asah Rp. 36.728. 
Berdasarkan data yang disajikan pengendalian gulma manual pada kegiatan gawangan Afdeling 1 biayanya lebih rendah/murah yaitu $R p$. 254.528/ha jika dibandingkan dengan biaya yang dibutuhkan gawangan Afdeling 2 yaitu Rp. 261.242/ha Adapun data yang disajikan pengendalian gulma manual pada piringan manual Afdeling 1 lebih tinggi/mahal yaitu Rp. 254.438/ha jika dibandingkan biaya yang dibutuhkan piringan Afdeling 2 yaitu Rp. 238. 787/ha.

d. Persentase Biaya

Hasil analisis biaya pada Afdeling 1 dan 2 untuk pelaksanaan kegiatan pengendalian gulma secara manual pada gawangan manual dan piringan manual, dapat dilhat Tabel 6.

Tabel 6. Persentase biaya Afdeling 1 dan 2

\begin{tabular}{clcccc}
\hline No & \multicolumn{1}{c}{ Kegiatan } & Afdeling 1 & $\%$ & Afdeling 2 & $\%$ \\
\hline 1 & Gawangan Manual & & & & \\
& Upah HK & Rp.11.772.412 & 98.15 & Rp. 4.556.600 & 95.36 \\
& Alat & Rp. 221.528 & 1,84 & Rp. 221.528 & 4.63 \\
\hline Sub total & & Rp.11.993.940 & & Rp. 4.778.128 & \\
\hline 2 & Piringan Manual & & & & \\
& Upah HK & Rp. 8.738.800 & 97.52 & Rp. 4.282.012 & 95.08 \\
& Alat & Rp. 221.528 & 2.47 & Rp. 221.528 & 4.91 \\
\hline Sub total & & Rp. 8.960.328 & & Rp. 4.503.540 & \\
\hline
\end{tabular}

Berdasarkan data persentase yang disajikan pada tabel 6 dapat dijelaskan bahwa komponen biaya dengan kebutuhan terbesar adalah tenaga kerja pada kegiatan gawangan Afdeling 1 yaitu sebesar $98.15 \%$ dan alat membutuhkan biaya $1.84 \%$, sedangan pada kegiatan piringan manual Afdeling 1 juga biaya tenaga kerja terbesar membutuhkan biaya sebesar 97.52\%, dan alat membutuhkan biaya $2.47 \%$.

Adapun persentase biaya pada kegiatan pengendalian gulma di gawangan secara manual Afdeling 2 kebutuhan biaya terbesar adalah tenaga kerja yaitu $95.36 \%$ dan komponen terkecil adalah biaya alat sebesar $4.63 \%$, sedangkan komponen terbesar pada pengendalian gulma di piringan secara manual Afdeling 2 juga tenaga kerja membutuhkan biaya 95.08\%, dan komponen terkecil adalah biaya alat sebesar $4.91 \%$.

\section{Faktor yang mempengaruhi biaya pengendalian gulma}

Faktor yang mempengaruhi beban biaya pengendalian gulma manual pada Afdeling 1 dan Afdeling 2 khususnya pada kegiatan gawangan manual dan piringan manual adalah topografi lahan, kepadatan gulma, jenis gulma dominan, dan cuaca diuraikan pada tabel 7 .

Tabel 7 . Faktor yang mempengaruhi biaya pengendalian gulma

\begin{tabular}{|c|c|c|c|c|c|}
\hline \multirow{2}{*}{ No. } & \multirow{2}{*}{ Kriteria } & \multicolumn{2}{|l|}{ Afdeling 1} & \multicolumn{2}{|c|}{ Afdeling 2} \\
\hline & & Gawangan & Piringan & Gawangan & Piringan \\
\hline 1 & Topografi lahan & Datar bergelombang & Datar & Bergelombang & Datar \\
\hline 2 & Kepadatan gulma & Sedang & Sedang & Cukup berat & Sedang \\
\hline 3 & $\begin{array}{l}\text { Jenis gulma } \\
\text { dominan }\end{array}$ & Acacia mangium Willd & $\begin{array}{l}\text { Acacia } \\
\text { mangium } \\
\text { Willd }\end{array}$ & $\begin{array}{l}\text { Gulma pakis } \\
\text { kawat }\end{array}$ & $\begin{array}{l}\text { Gulma } \\
\text { pakis } \\
\text { kawat }\end{array}$ \\
\hline 4 & Cuaca & Musim kemarau & $\begin{array}{l}\text { Musim } \\
\text { kemarau }\end{array}$ & $\begin{array}{l}\text { Musim } \\
\text { kemarau }\end{array}$ & $\begin{array}{l}\text { Musim } \\
\text { kemarau }\end{array}$ \\
\hline
\end{tabular}


Dari uraian tabel 7 di atas, dapat dilihat bahwa faktor yang mempengaruhi beban biaya pengendalian gulma manual pada gawangan Afdeling 1 dan piringan Afdeling 1 yaitu topografi lahan datar bergelombang, kepadatan gulma yang sedang, jenis gulma Acacia mangium

\section{Pembahasan}

1. Perbandingan Biaya

Dari hasil perbandingan biaya Afdeling 1 pada gawangan lebih rendah/murah yaitu Rp. 254.756/ha jika dibandingkan dengan gawangan Afdeling 2 yaitu Rp. 261.242/ha terdapat selisih Rp. 6.468/ha nya. Sedangkan piringan Afdeling 1 lebih mahal yaitu Rp. 254.438/ha jika dibandingkan dengan piringan Afdeling 2 yaitu Rp. 238.787/ha terdapat selisih Rp. 15.698/ha hal ini dikarenakan adanya
Willd, dan cuaca yang sedang kemarau. Adapun pada gawangan Afdeling 2 dan piringan Afdeling 2 yaitu tofografi lahan bergelombang datar, kepadatan gulma yang cukup berat, jenis gulma dominan gulma pakis, dan cuaca yang sedang kemarau.

perbedaan pada struktur biaya, kondisi lahan dan alat.

2. Struktur alokasi biaya

Dalam pelaksanaan kegiatan pengendalian gulma secara manual pada gawangan dan piringan, tenaga kerja dibutuhkan sebagai pelaksana kegiatan di lapangan. Kebutuhan tenaga kerja dari 2 afdeling yang diamati, disajikan pada tabel 8.

Tabel 8. Perbandingan kebutuhan tenaga kerja Afdeling 1 dan 2

\begin{tabular}{|c|c|c|c|c|}
\hline Afdeling & Kegiatan & Keterangan & $\begin{array}{c}\text { Periode Kerja } \\
(2019)\end{array}$ & Total \\
\hline \multirow[t]{4}{*}{1} & Gawangan Manual & $\begin{array}{c}\text { Kebutuhan Tenaga Kerja } \\
\text { Realisasi }\end{array}$ & Februari-April & $\begin{array}{l}94.30 \\
47.08\end{array}$ \\
\hline & $\mathrm{HK} / \mathrm{ha}$ & & & 2.00 \\
\hline & Piringan Manual & $\begin{array}{c}\text { Kebutuhan Tenaga Kerja } \\
\text { Realisasi }\end{array}$ & Februari-April & $\begin{array}{l}70,00 \\
35.21\end{array}$ \\
\hline & HK/ha & & & 2.00 \\
\hline \multirow[t]{4}{*}{2} & Gawangan Manual & $\begin{array}{c}\text { Kebutuhan Tenaga Kerja } \\
\text { Realisasi }\end{array}$ & Februari-April & $\begin{array}{l}37.20 \\
18.29\end{array}$ \\
\hline & $\mathrm{HK} / \mathrm{ha}$ & & & 2.03 \\
\hline & Piringan Manual & $\begin{array}{c}\text { Kebutuhan Tenaga Kerja } \\
\text { Realisasi }\end{array}$ & Februari-April & $\begin{array}{c}34.3 \\
18.86\end{array}$ \\
\hline & $\mathrm{HK} / \mathrm{ha}$ & & & 1.82 \\
\hline
\end{tabular}

Pemakaian HK yang disajikan tabel 8, pada Afdeling 1 adalah 2.00 $\mathrm{HK} / \mathrm{ha}$ untuk pekerjaan gawangan manual dan Afdeling 2 adalah $2.03 \mathrm{HK} / \mathrm{ha}$ untuk pekerjaan gawangan manual, pemakaian HK untuk pekerjaan piringan manual Afdeling 1 adalah $2.00 \mathrm{HK} / \mathrm{ha}$ sedangkan pemakaian HK pada Afdeling 2 adalah $1.82 \mathrm{HK} / \mathrm{ha}$ untuk pekerjaan

\section{Faktor yang mempengaruhi biaya} pengendalian gulma

$$
\text { Adapun faktor yang }
$$
mempengaruhi biaya adalah topografi lahan, kepadatan gulma, jenis gulma yang dominan, dan cuaca. piringan manual. Menurut Sumarsono (2009) yang menyatakan bahwa tenaga kerja atau sumber daya manusia (SDM) menyangkut manusia yang mampu bekerja untuk memberikan jasa atau usaha kerja. Mampu bekerja berarti mampu melakukan kegiatan yang menghasilkan nilai ekonomis.

\section{a. Topografi Lahan}

Berdasarkan hasil observasi pada gawangan Afdeling 1 memiliki kondisi topografi yang datar dan bergelombang sedangkan pada Afdeling 2 memiliki topografi yang bergelombang, dengan kondisi topografi kedua Afdeling diduga 
memberikan pengaruh terhadap penggunaan tenaga kerja. Hal ini dapat dilihat pada hasil kegiatan pengendalian gulma di gawangan manual Afdeling 1 kebutuhan tenaga kerja sebesar 2.00 $\mathrm{HK} / \mathrm{ha}$ sedangkan pada afdeling 2 sebesar $2.03 \mathrm{HK} / \mathrm{ha}$.

Adapun piringan Afdeling 1 memiliki kondisi topografi yang datar sedangkan piringan Afdeling 2 juga datar. Dokumentasi dapat dilihat pada Lampiran 8 Gambar 3. Menurut pendapat Adrianus dkk., (2018) topografi berupa kemiringan dan tinggi rendahnya suatu lahan mempengaruhi produktifitas budidaya tanaman kelapa sawit.

b. Kepadatan Gulma

Selain kondisi topografi lahan faktor lainya adalah kondisi kepadatan gulma Afdeling 1 pada gawangan memiliki kepadatan gulma yang sedang sedangkan Afdeling 2 pada gawangan memiliki kepadatan gulma yang cukup berat. Kondisi tersebut diduga akan memberikan dampak bagi pelaksanaan pengendalian gulma secara manual dikarenakan kondisi gulma dengan kepadatan gulma yang cukup berat membutuhkan waktu yang lebih lama dalam kegiatan pengendaliannya. Kondisi kepadatan yang berat akan menghambat jalannya perkerjaan dan membutuhkan waktu yang lebih sehingga kebutuhan tenaga kerja untuk menyelesaikan pekerjaan akan lebih tinggi.

Dari hasil observasi kepadatan gulma Afdeling 1 dan Afdeling 2 pada piringan sama-sama memiliki kepadatan gulma yang sedang. Dokumentasi dapat dilihat pada Lampiran 8 Gambar 4. Menurut pendapat Moenandir (2010) yang menyatakan bahwa kepadatan gulma adalah hubungan antara jumlah individu dari suatu spesies atau semua spesies pada suatu luasan atau ruang, bagian luasan tanah yang tertutupi oleh vegetasi.

c. Jenis Gulma Dominan

Selain kepadatan gulma faktor lainya adalah dengan adanya jenis gulma kayu Acacia magium berpengaruh bagi pengendalian gulma manual. Menurut Krisnawati dkk., (2011) Acaci magium yang dikenal dengan magium merupakan salah satu jenis gulma kayu yang paling cepat tumbuh yang umum digunakan dalam program pembangunan hutan tanaman di Asia dan Pasifik seperti hasil observasi pada gawangan Afdeling 1 dan piringan Afdeling 1.

Sedangkan jenis gulma pakis juga berpengaruh pada biaya pengendalian gulma hal ini dikarenakan kepadatan gulma cukup berat. Menurut Prawiro dkk., (2005) gulma pakis Dicratnopteris linearis termasuk pakis tahunan yang merambat batangnya licin, keras dan berdiri tegak. Sangat toleran terhadap tanah yang kering dan pakis ini merupakan pesaing dalam pemanfaatan usur hara dan air bagi tanaman pokok kelapa sawit. Seperti hasil observasi pada gawangan Afdeling 2 dan piringan Afdeling 2. Dokumentasi dapat dilihat pada Lampiran 8 Gambar 5 dan 6.

d. Cuaca

Cuaca pada saat kegiatan pengendalian saat itu sedang kemarau sehingga diduga tidak terlalu mempengaruhi biaya pengendalian gulma. Sebaliknya diduga jika musim hujan yang akan berpengaruh besar terhadap kegiatan pengendalian gulma manual bila terjadi hujan sebelum karywan berada di lapangan maka pekerjaan dapat dialihkan terlebih dahulu tetapi, apabila terjadi hujan saat pekerjaan sedang berjalan maka pekerjaan akan dihentikan sementara atau karyawan dipulangkan sehingga target kerja tidak dapat tercapai.

Dari hasil observasi data curah hujan yang di proleh dari perusahaan pada bulan Februari dengan curah hujan (260.32 mm) termasuk dalam kategori curah hujan menengah, bulan Maret dengan curah hujan (416.35 $\mathrm{mm})$ termasuk dalam kategori curah hujan tinggi, dan pada bulan April dengan curah hujan ( $327.75 \mathrm{~mm}$ ) termasuk dalam kategori curah hujan tinggi. Dapat dilihat pada Lampiran 7.

Menurut pendapat Barus (2003) bahwa faktor lingkungan dapat mempengaruhi efektivitas dan efisiensi kegiatan seperti curah hujan. Hal ini sesuai dengan pendapat Saputra dan Lontoh (2018) yang menyatakan bahwa 
faktor iklim sangat berpengaruh langsung adalah curah hujan. Intensitas curah hujan yang tinggi akan menghambat kegiatan pengendalian gulma sehingga memungkinkan adanya areal yang belum dikerjakan.

\section{Alat}

Dari hasil pengamatan di lapangan alat yang digunakan masih kurang memadai seperti parang yang digunakan kurang sesuai untuk pengendalian gulma dengan jenis Acaci magium dan pakis kawat di gawangan dan piringan pada kedua Afdeling.Kebutuhan alat masing-masing Afdeling dipengaruhi oleh kondisi alat yang dimiliki Afdeling, bila terdapat peralatan yang rusak maka Afdeling akan melakukan permintaan pergantian alat sesuai dengan kebutuhan kerja karyawan.

Hal ini sejalan dengan pendapat Saputra dan Lontoh (2018) yang menyatakan bahwa ketersedian alat dan penyediaan akan berpengaruh terhadap rencana kerja pengendalian gulma, karena beberapa masalah pada peralatan yang kurang memadai akan membuat waktu kerja semakin sedikit dan target kerja tidak terpenuhi begitupun sebaliknya.

\section{KESIMPULAN}

Dari hasil peneitian analisis biaya pengendalian gulma secara manual yang diuraikan sebelumnya, maka dapat disimpulkan:

1. Biaya pengendalian gulma secara manual di gawangan pada Afdeling 1 adalah Rp. 254.756 /ha dan biaya gawangan pada Afdeling 2 adalah Rp. 261.242 /ha yang berarti bahwa biaya pengendalian gulma secara manual pada gawangan di Afdeling 1 lebih rendah/murah jika dibandingkan dengan Afdeling 2.

2. Biaya pengendalian gulma secara manual di piringan pada Afdeling 1 adalah Rp. 254.483/ha sedangkan Biaya pengendalian gulma secara manual di piringan pada Afdeling 2 Rp. 238.787/ha yang berarti biaya pengendalian gulma secara manual pada piringan di Afdeling 2 lebih rendah/murah dibandingkan dengan Afdeling 1.

3. Faktor yang mempengaruhi biaya pengendalian gulma secara manual pada tanaman belum menghasilkan (TBM) khusunya di piringan dan di gawangan lebih disebabkan oleh faktor kondisi topografi lahan, kepadatan gulma, jenis gulma yang dikendalikan.

\section{DAFTAR PUSTAKA}

Adrianus S, W. H. (2018). Kajian Kemiringan Lahan Terhadap Produksi Kelapa Sawit. Jurnal Agromas.

Barus, E. (2003). Pengendalian Gulma di Perkebunan. Yogyakarta: Kanisius.

Krisnawati H, K. M. (2011). Ekologi Silvikultur dan Produktivitas. Bogor: CIFOR.

Moenandir, J. (2010). IImu Gulma. Malang: Universitas Brawijaya Press.

P, S. Y. (2018). Manajemen Pengendalian Gulma Tanaman Kelapa Sawit (Elaesis Guineesis Jacq) di Kebun Aneka Persada Riau.

Prawirosukarto. S, E. S. (2005). Tanaman Penutup Tanah dan Gulma pada Kebun Kelapa Sawit. Medan: Pusat Penelitian Kelapa Sawit.

Purwanto. (2016). Tips Sukses Usaha dan Berkebun Sawit. Depok: Palapa.

S, S. (2003). Budidaya Kelapa Sawit. Jakarta: AgroMedia Pustaka.

S, S. (2009). Teori dan Kebijakan Publik Ekonomi Sumber Daya Manusia. Yogyakarta: Graha IImi.

Sunarko. (2007). Petunjuk Praktis Budidaya \& Pengolahan Kelapa Sawit. Jakarta: AgroMedia Pustaka. 